\title{
Antiviral therapy in acute viral hepatitis B: why and when Giuseppe Morelli1 ${ }^{1}$ Alessandro Perrella*1,2, Costanza Sbreglia1, Pasquale Bellopede ${ }^{1}$, Vincenzo Riccio ${ }^{1}$, Antonio Monaco ${ }^{1}$ and Oreste Perrella ${ }^{1}$
}

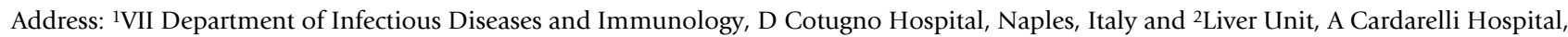
Naples, Italy

Email: Giuseppe Morelli - pinomorelli25@libero.it; Alessandro Perrella* - alexperrel@virgilio.it; Costanza Sbreglia - drcosty@libero.it; Pasquale Bellopede - pbellop@libero.it; Vincenzo Riccio - alexperrel@virgilio.it; Antonio Monaco - alexperrel@virgilio.it; Oreste Perrella - oreste.perrella@ospedalecotugno.it

* Corresponding author

Published: I April 2009

Infectious Agents and Cancer 2009, 4:5 doi:10.1186/1750-9378-4-5

Received: 27 March 2009

Accepted: I April 2009

This article is available from: http://www.infectagentscancer.com/content/4/I/5

(c) 2009 Morelli et al; licensee BioMed Central Ltd.

This is an Open Access article distributed under the terms of the Creative Commons Attribution License (http://creativecommons.org/licenses/by/2.0), which permits unrestricted use, distribution, and reproduction in any medium, provided the original work is properly cited.

\section{Abstract}

Correction to Morelli G, Perrella A, Sbreglia C, Bellopede P, Riccio V, Perrella O: Antiviral therapy in acute viral hepatitis B: why and when. Infectious Agents and Cancer 2009, 4:2. 


\section{Correction}

After publication of this work [1], we noted that we inadvertently failed to include the complete list of all coauthors. The full list of authors has now been corrected here and the Authors' contributions and Competing interests section modified accordingly (see below).

\section{Competing interests}

The authors declare that they have no competing interests.

\section{Authors' contributions}

GM, AP were involved in preparation of data analysis, preparation of the manuscript and study coordination; $\mathrm{CS}, \mathrm{PB}, \mathrm{VR}$, AM were involved in clinical investigation; OP was involved in idea writing of the manuscript, principal investigator and responsible for the study.

\section{References}

I. Morelli G, Perrella A, Sbreglia C, Bellopede P, Riccio V, Perrella O: Antiviral therapy in acute viral hepatitis $B:$ why and when. Infectious Agents and Cancer 2009, 4:2.

Publish with Bio Med Central and every scientist can read your work free of charge

"BioMed Central will be the most significant development for disseminating the results of biomedical research in our lifetime."

Sir Paul Nurse, Cancer Research UK

Your research papers will be:

- available free of charge to the entire biomedical community

- peer reviewed and published immediately upon acceptance

- cited in PubMed and archived on PubMed Central

- yours - you keep the copyright

Submit your manuscript here:

http://www.biomedcentral.com/info/publishing_adv.asp 